\title{
Uluslararası Fuarlar ve Zihinsel Mesafe
} (Araştırma Makalesi)

\author{
International Exhibitions and Psychic Distance
}

Doi: 10.29023/alanyaakademik.706465

\section{Betül Kübra SUNGUR}

Mezun, Yalova Üniversitesi Sosyal Bilimler Enstitüsü

b.k.sungur@hotmail.com

Orcid No: 0000-0001-0001-0000

\author{
Aytuğ SÖZÜER \\ Doç.Dr, Yalova Üniversitesi, İBF, Uluslararası Ticaret ve Finansman Bölümü \\ aytug.sozuer@yalova.edu.tr
}

Orcid No: 0000-0003-2680-2071

Bu makaleye atıfta bulunmak için: Sungur B.K., Sözüer A. (2020). "Uluslararası Fuarlar ve Zihinsel Mesafe”, Alanya Akademik Bakış, 4(3), Sayfa No. 889-910.

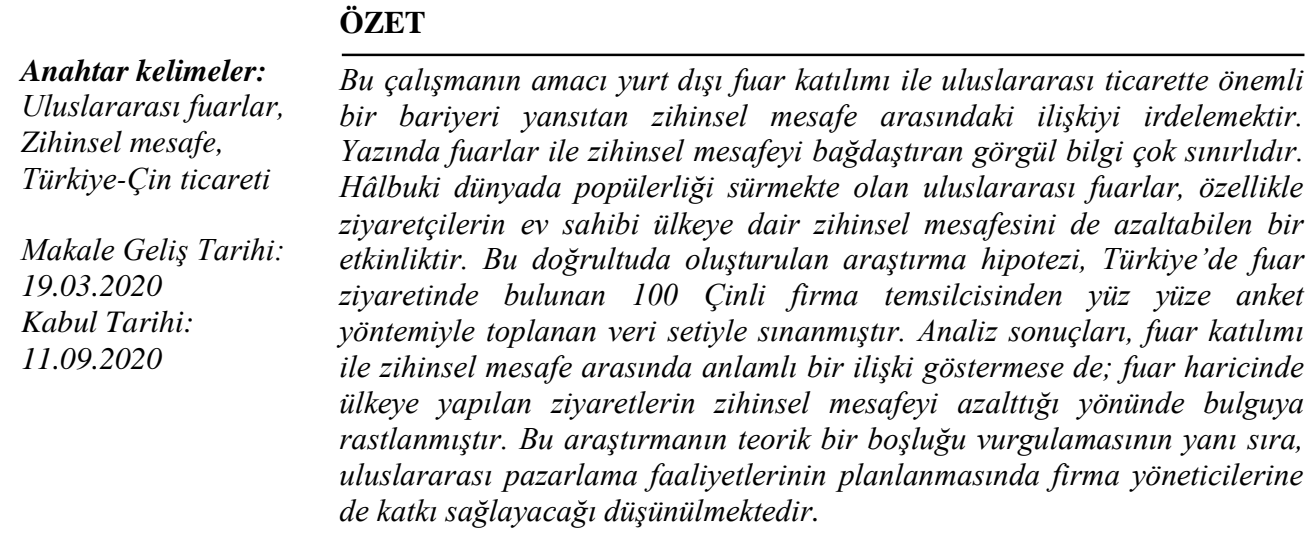


Keywords: International exhibitions, Psychic distance, Turkey-China trade

\begin{abstract}
The purpose of this study is to investigate the relationship between attending exhibitions abroad and psychic distance (PD), which reflects an important barrier to international trade. The empirical knowledge regarding to the connection between exhibitions and PD is rather limited. Nevertheless, international fairs, which are still popular worldwide, are organizations that can diminish PD especially from the perspective of visitors against the host country. Respectfully, a research hypothesis is developed and tested by examining data collected from 100 Chinese firm representatives visiting exhibitions in Turkey by face-to-face surveys. Although results do not show significant relationship between international fair attendance and $P D$, it is revealed that country visits apart from exhibitions decrease PD. The research contributes to the relevant literature by pinpointing a theoretical gap as well as has implications for business managers in terms of international marketing planning.
\end{abstract}

\section{GİRISŞ}

İşletmelerin ticari sınırların azaldığı ve rekabetin karmaşıklaştı̆̆ günümüz iş çevresine uyum sağlamaları gerekmektedir. Yaygınlığı artan faaliyetlerden biri; ürün ve hizmetlerin yurt dışı pazarlarda daha geniş müşteri kitlesine sunabilmek amacıyla yürütülen uluslararası ticarettir. 1990-2018 yılları arasında dünyadaki yıllık ürün ve hizmet ihracat hacmi 4,3 trilyon ABD Doları seviyesinden -yaklaşık altıya katlanarak- 25,1 trilyon ABD Dolarının üzerine çıkmışırı (Dünya Bankası, 2020). Diğer yandan, yabancı bir pazarda iş yapmak belirsizliklerin fazlalaşıtı̆ı bir süreçtir. Ortaya çıkan yeni risklerin ancak çeşitli taraflarla iletişim kurarak ve bilgi paylaşarak azaldığı varsayılabilir. Bu çalışmada, yaygın bir ticari etkinlik olarak uluslararası fuarlar ile yabancılarla anlaşabilme engellerini yansıtan zihinsel mesafe kavramı arasındaki ilişki incelenecektir.

İlk çağlardan bu yana tüccarların uzak pazarları tanımak ve onlarla iş yapabilmek için sıkça kullandı̆̆ 1 yöntemlerden biri, alıcı ve satıcıyı bir araya getiren pazar yerlerinde veya güncel endüstriyel adıyla fuarlarda yer almaktır. Buralarda satıcılar bir sergi alanı açarak ürün ve hizmetlerini sergileyebilir veya diğer satıcıları ziyaret ederek yeniliklerden haberdar olabilirler. Öte yandan alıcılar da bu etkinliklerde ihtiyaçları olan veya ilgilerini çeken ürünleri bizzat inceleyebilir ve bunların tedarikçileriyle buluşabilirler.

Fuarlar, işletmecilik yazınında çeşitli yönlerden ele alınarak irdelenmiştir. Araştırmaların bir bölümü sektör olarak fuarcılığı, bunun gelişimini, katılımcı ve organizatörler arasındaki ilişkileri ve ekonomiye katkılarını incelemektedir (Pehlivan, 1996; Gregory ve Breiter, 2001; Paker, 2009; Jin vd., 2012). Diğer bir kısım çalışmalar fuarların pazarlama ve satış geliştirme gibi işletme fonksiyonları üzerindeki etkilerini ve fuar performansının arttırılması için yapılması gerekenleri ele almaktadır (Gürel, 1998; Tanner, 2002; Sohodol, 2003; Hansen, 2004; Koldaş, 2006; Li, 2010; İnce, 2013; Sarmento vd., 2015; Aksoy, 2016; Aytekin, 2017; Tuerxun, 2017). Öte yandan, özellikle Yerli yazında yer bulan bazı çalışmalarda ise; firmaların fuarlara katılımını teşvik eden devlet destekleri ve bu desteklerin etki ve yeterlilikleri değerlendirilmektedir (Sülün, 2006).

Zihinsel mesafe (psychic distance) Beckerman (1956)'nın tarifinden sonra yazında uluslararası ticareti zorlaştıran etkenleri açıklamak üzere tartışılagelen bir kavramdır. Genel 
kabul gören bazı çalışmalarda (ör. Johanson ve Wiedersheim-Paul, 1975; Johanson ve Vahlne, 1977; Evans ve Mavondo, 2002; Prime vd. 2009) zihinsel mesafe kavramı ölçülebilir hale getirilmeye çalışılmıştır. Bu çabanın gerekçesi; zihinsel mesafeyi oluşturan taraflar arasındaki farklılıkların önce anlaşılıp, sonra yönetilmesini sağlamaktır. Çünkü bu farklılıklar uluslararası ticaretin önünde engel oluşturmakta; bunların denetiminin ise firmalara yeni pazarlara giriş kararlarında fayda sağlaması beklenmektedir.

İlgili yazın incelendiğinde, fuarlar ile zihinsel mesafe arasındaki ilişkiye dair bilgi çok sınırlıdır. Türkiye bağlamında zihinsel mesafe çeşitli açılardan incelenmiş (ör. Sümer, 2011; Gödekmerdan, 2012; Karakaş, 2013; Arslan, 2016) fakat endüstriyel fuarlar ile irtibatını kuran başka esere rastlanılmamıştır. Bu çalışmanın fuarların uluslararası ticarette önemli bir bariyeri yansıtan zihinsel mesafe durumuna olası etkilerini değerlendirmesi bakımından uygulamacılara da katkı sağlayacağı düşünülmektedir.

Çalışmada öncelikle fuarlar ile zihinsel mesafe olguları tanımlanacak ve ilgili yazından örnekler verilecek; ardından konu hakkında yapılan saha araştırması açıklanacak ve bulgular değerlendirilecektir.

\section{YAZIN INCELEMESI VE HIPOTEZ}

\subsection{Fuarlar}

Fuarlar ticareti geliştirmek amacıyla alıcı ve satıcıyı; başka bir ifadeyle arz ve talebi buluşturan organizasyonlar olarak tanımlanabilir. Ürünlerin veya hizmetlerin, bilgilerin, yeniliklerin ve teknolojik gelişmelerin tanıtılması, yeni pazar bulunabilmesi, geleceğe yönelik ilişkilerin kurulması, teknik iş birliği sağlanması ve bunların geliştirilmesi için gerçekleştirilen bir etkinliktir (Sohodol, 2003: 76). Fuarlar ekonomik, ticari, politik ve kültürel platformların buluşma noktasıdır ve bir tanıtım misyonu taşımaktadır (Gürel, 1998: 1). Keza 2019 yılında Türkiye'de düzenlenen 482 fuar ve bunları ziyaret eden yaklaşık 720 bini yabancı 25 milyonun üzerinde ziyaretçinin bulunması, fuarların ülke adına da önemli bir ticari etkinlik olduğunu yansıtmaktadır (TOBB, 2020).

Öncelikli olarak fuarlar ticari mal, hizmet ve bunlara ilişkin teknolojik gelişmelerin ve yeniliklerin tanıtımının yapılmasını amaçlar. Katılımcılar ve ziyaretçiler etkileşim içerisindedirler. Fuarın konusuyla ilgili insanları bir araya getirmesi sayesinde, ziyaretçi ve katılımcılar arasında bilgi alışverişi sağlanır; iş birliği kurulması ve geliştirilmesi için gerekli ortam yaratılır. Bunlara paralel olarak pazarın büyütülmesi, satışların arttırılması ve ticaretin geliştirilmesi amaçlanır. Fuarların adı, konusu, türü ve düzenleyicisi gibi tüm detayları önceden bellidir. Fuarlar düzenli aralıklarla senede bir-iki ya da iki senede bir olacak şekilde belirli zamanlarda ve yerde organize edilir. Genellikle de aynı dönemlerde ve yerlerde tekrarlanırlar (Sohodol, 2003: 76; TOBB, 2015: 2).

Fuarlar düzenlenme amacına göre ikiye ayrılabilmektedir. Bunlardan ilki belirli bir sektör ya da ürün grubu üzerine odaklanmayan, farklı mal ve hizmetlerin beraber sergilendiği genel fuarlardır. $\mathrm{Bu}$ etkinliklerde çeşitli sektörlere ait ürünler ve hizmetlerin tanıtımı yapılır. Hammadde, yarı-mamul ve nihai tüketim ürünleri beraberce aynı organizasyonda sergilenir. Çeşitli sosyal ve kültürel etkinlikleri içerebilir. Her yaştan ve beğeni grubundan ziyaretçilerin ilgisini çekmek amaçlanmaktadır ve umumi ziyarete açıktır (MEB, 2011).

Fuarların diğer türü belirli bir ürün veya hizmet grubu üzerine odaklanan ya da doğrudan bir veya birkaç sektör veya iş kolu ile ilişkili olarak düzenlenen ihtisas fuarlardır (TOBB, 2015; 
Erdemir, 2017). Bu etkinliklerde sektörle ilişkili üreticiler ve tüketiciler bir araya gelmektedir (Gürel, 1998: 4). Ayrıca, ihtisas fuarları da kendi içinde endüstriyel ve tüketici fuarları olarak ikiyi ayrılabilir. Endüstriyel fuarlarda hedef kitle kurumlar; tüketici fuarlarında potansiyel müşteriler ve bireyler olabilir. Diğer bir ifadeyle, etkinlik perakende satışları da kapsayabilir (TOBB, 2015).

Fuarlar başlangıçta mal ve hizmetlerin tanıtımı için düşünülmüş bir çözüm olsa da, zamanla pek çok işlev kazanmıştır. Günümüzde fuarların sahip olduğu önem ancak onun işlevleriyle beraber açıklanabilir. Fuarların işlevleri genel hatlarıyla aşağıda derlenmiştir (Gürel, 1998; Hansen, 2004; Koldaş, 2006; Sülün, 2006; Çekiç, 2009; Sarmento vd., 2015; Aytekin, 2017).

- Tanıtım, pazarlama ve imaj oluşturma işlevi: Günümüzde küreselleşmeyle birlikte artan rekabet koşulları, hızlı gelişen ve değişen uygulamalar ve teknolojiler firmaları uluslararası alanda daha fazla boy göstermeye itmektedir. Firmalar müşterilerine daha yakın olmak, sektörde tanınırlı̆̆ını hep taze tutmak ister. Fuarlar, katılımcı firmalara kendi kurumsal tanıtımlarını yapmanın yanı sıra ürün ve hizmetlerini pazarlama imkânı sunar.

- Satış geliştirme işlevi: Fuarların ortaya çıkışından itibaren, amaçlarının en başında satış geliştirmenin geldiğini söylenebilir. Katılımcılar, satışlarını artırmak üzere fuarları pazarlama planlarına dâhil ederler. Fuarlar sayesinde potansiyel müşterilerini gerçek müşterileri haline getirebilirler ve yeni ürünleri için pazar araştırması yapabilirler.

- İlişski geliştirme işlevi: Bu işlev, alıcı ve satıcıların veya işbirlikçilerin yüz yüze gelerek iletişim kurabilmesi sayesinde gerçekleşir. Fuarlar sayesinde bir araya gelmek, ilişkilerin kurulmasına ve ilerletilmesine katkı yapar. Satıcıların müşteriyle iyi ilişkilere sahip olması ürünlerin tanıtımında ve satışında önemli faydalar sağlamaktadır.

- Talebi doğrudan anlama işlevi: Fuar sırasında müşteriler ile yüz yüze iletişim kurmak müşterinin talebinin kısa sürede ve en etkili şekilde anlaşılmasını sağlar. Bu sayede gerekli tanıtım ve pazarlama doğrudan yapılır ve satış daha hızlı şekilde gerçekleşebilir.

- İşbirliği oluşturma işlevi: Fuarlar alıcı ve satıcıları, üretici ve tüketicileri bir araya getirdiği gibi o konuyla ilgili iş yapmak isteyen kişi ve kurumları da buluşturur. Bu kişi ve kurumlar da fuarda yapacakları görüşmeler ile aralarında ortaklıklar veya yeni iş bağlantıları inşa edebilirler. Üreticiler distribütör, bayi veya doğrudan satıcılarla buluşarak ürünlerinin satış ağını genişletip, farklı bölgeler için dağıtım kanallarını geliştirebilirler.

- Bilgi ve fikir paylaşımı işlevi: Fuarlar sayesinde kişiler ve kurumlar karşılıklı görüşmelerle ürün, hizmet, sektör ve rakiplerinin gelişimi hakkında da bilgi edinirler.

- Sektöre yön verme işlevi: Hem katılımcılar hem de ziyaretçiler fuarlar sayesinde sektördeki gelişmelerden haberdar olur ve sergilenen yenilikleri gözlemler. $\mathrm{Bu}$ paylaşımlar hem üretim ve hem de ticaret süreçlerinde gelişimi hızlandırarak sektöre yön verebilir.

Fuarlar, ticari hayatında önemli bir yer kaplamaları dolayısıyla, işletmecilik yazınında yapılan pek çok çalışmaya da konu olmuştur. Bu çalışmalar genel itibariyle; bir sektör olarak fuarcılığın gelişimini, firmalara ve genel ekonomiye olan katkılarını ve bu etkinliklere ilişkin kamu desteklerini ele almıştır. Böyle geniş bir yazın içinde, fuarların özellikle ticari faaliyetlerle ilişkisine dair yapılmış bazı çalışmalar aşağıda sunulmuştur.

Gregory ve Breiter (2001) çalışmalarında ticaret fuarlarının organize edilmesi ve yönetilmesinde yeni teknolojilerin kullanılmasının stratejik önemini vurgulamışlardır. Çalışmada, fuar organizatörlerinin katılımcılar ile etkileşim içinde kalmak için günden güne 
teknolojiden daha fazla faydalandıkları; özellikle internet kullanımının fuarların etkisini ve verimliliğini artırmada merkezi bir öneme sahip olduğu sonucuna ulaşılmıştır.

Tanner (2002) fuarlara katılan küçük işletmelerin başarılı olanları ile başarısız olanlarını karşılaştırmış ve firmalara yol göstermesi amacıyla başarıya ulaşanların neler yaptığını açıklamıştır. Yazara göre etkin firmalar fuar katılımlarının daha kullanışlı hale gelmesini sağlayacak bir uzmanla birlikte çalışmaktadır. Fuar organizasyonunu yürütmede yetki ve sorumluluk bir kişiye verilmiştir. Daha az başarılı olan firmalara da koordine edilmiş bir pazarlama iletişimi planı geliştirilmesini ve bu sayede başarıya ulaşmak için ihtiyaç duyulan uzman görüşü alınmasını tavsiye etmektedir.

Hansen (2004) fuar performansı ölçümüne ilişkin bir çalışma yapmıştır. Ortaya koyduğu davranış temelli ölçüm boyutlarında katılımcı olunan fuarda bilgi toplama, ilişki geliştirme, imaj oluşturma ve motivasyon aktiviteleri gibi işlevlerin öne çıktığını göstermiştir.

Li (2010) ortaya koyduğu çalışma ile internet kullanımının fuar performansına etkisini katılımcılar açısından ele almıştır. İnternet kullanımının fuardan önce, fuar sırasında ve fuardan sonra olmak üzere tüm aşamalarda güçlü bir etkisi olduğunu savunmuştur. Firmalar internet sitelerinde katılımcı olacakları fuara ilişkin bilgileri yayınlayarak fuar öncesi tanıtımlarını kolaylaştırmakta; fuar sırasında ve sonrasında da internet bağlantıları aracılığıyla müşterilerine hizmet sağlayabilmekte ve onların taleplerini takip edebilmektedir.

Jin vd. (2012)'in çalışmasında ise katılımcılar ile organizatörler arasındaki ilişki ele alınmış ve ikisi arasındaki ilişkinin şu dört temelde değerlendirilebileceği öne sürülmüştür: (1) Servis kalitesi ve ilişsi memnuniyeti, (2) güven ve etkili taahhüt, (3) iletişim, (4) hesaplanabilir mutabakat. Yazarlara göre bahsedilen dört boyutta doğru ilerleme sağlanabildiği durumda katılımcı ile organizatör arasındaki ilişkinin kalitesi de doğru orantılı olarak artmaktadır.

Sarmento vd. (2015) ilişkisel pazarlama perspektifinden ticari fuarları değerlendirmiştir. Yazarlara göre uluslararası ticari fuarlar bireylerin sosyalleşme davranışlarını, firmalar arasındaki bağlılığı ve güveni yaratmak konusunda faydalıdır ve bu sayede ilişkilerinin kalitesini arttırır.

Türkiye bağlamında fuarları irdeleyen çalışmalara da sıkça rastlanmaktadır.

Pehlivan (1996) fuarların kuruluşlar için ne kadar önemli olduğunu vurgulamış, Türkiye ve Avrupa'daki fuarcılığı karşılaştırmıştır. Öte yanda, bu denli önemli olan fuarların Türkiye'de etkin şekilde kullanılamadığı yönünde eleştirel bir çalışma ortaya koymuştur.

Gürel (1998) iletişim ve teknolojideki yeniliklerle ilişkili olarak gelişmesini sürdüren fuarlarda katılımcıların başarılı olabilmesi ve fayda/maliyet oranını yükseltebilmesi için fuar sonrasındaki çalışmalarına önem vermesi gerektiğini vurgulamıştır. Yazara göre fuarların katılımcılara fayda sağlayabilmesi, fuar sırasında kurulan iletişim ortamının fuardan sonra da sürdürülmesiyle mümkün olmaktadır.

Sohodol (2003) çalışmasında hem organizatörler hem de katılımcıların fuarlara hazırlık aşamasında stratejik bir planlama yapması gerektiğini savunmuştur. Söz konusu bu stratejik planlamanın yapılması durumunda hem katılımcı hem de organizatör firma çok olumlu sonuçlar elde edebilmektedir.

Sülün (2006) ise fuarları ihracatı geliştirmenin en önemli yöntemlerden biri olarak ifade etmiştir. Türkiye'deki firmaların fuarlara katılımının yetersiz olduğunu, bunu sebebinin ise 
fuarların profesyonel bir temele oturtulamaması ve firmaların fuarlara katıldıklarında elde edecekleri faydalar konusunda yeterli bilince sahip olmaması olarak görmektedir. Çalışmanın temelinde ülke ekonomisine önemli katkısı olan fuar organizasyonlarına yönelik kamusal teşviklerin daha çok yaygınlaştırılması ve etkinliğinin arttırılması gerektiği öne sürülmektedir.

Koldaş (2006) fuarların satış geliştirme etkisini ele almış; çalışması kapsamında uyguladığı anket ile katılımcı firmaların fuarları ürün tanıtımı konusunda katalog ve broşürlerden sonra üçüncü sırada önemli gördügünü; satış geliştirme konusunda da fiyat indiriminden sonra ikinci sırada önemli bulduğunu ortaya koymuştur.

Paker (2009) öncelikle Türkiye'deki fuarcılık sektörünü ele alarak dünyadaki diğer fuar ülkeleriyle kıyaslamış ve böylelikle Türkiye'nin fuarcılık konusunda dünyadaki yerini açıklamıştır. Son yıllarda ülkelerin ekonomilerine önemli katkılar sağlayan fuarcılık sektöründe Türkiye'nin özellikle bölgesel rakipleri olan Rusya ve Birleşik Arap Emirlikleri'nden geride kaldığını ifade etmiş ve doğru devlet politikaları ile bunun aşılabileceğini savunmuştur. Çalışmasında düzenleyicilerin, fuar satışını geliştirmek için iç ve dış kaynakları etkin şekilde kullanması gerektiğini vurgulamaktadır. Dış kaynak olarak kastedilen dernekler, odalar, birlikler, kitle iletişim araçları, sektörel dergiler, oda veya fuarların satışını destekleyen kurumlardır. İç kaynaklarlar ise; organizatör firmanın kendi geliştirdiği satış geliştirme araçları veya faaliyetleridir. E-posta, faks, satış personelinin yaptığı yüz yüze görüşmeler ve fuar faaliyetlerini destekleyici teşviklerin çıkartılması, bunlardan bazılarıdır.

İnce (2013) küçük ve orta boy işletmelerin (KOBİ) ihtisas fuarlarına yaklaşımını ele almıştır. Gelişen dünya pazarında KOBİ'lerin de büyümesi, yeni pazarlarda çalışabilmesi için doğru pazarlama stratejileriyle etkili faaliyetlerde bulunması gerektiği vurgulanmıştır. Yapılan araştırma sonucunda KOBİ'lerin pazarlama faaliyetlerini çoğunlukla kendi sektörleriyle ilgili fuarlara, sektörel dergilere, kişisel bağlantılara ve müşteri kitlesine yönelik organizasyonlara dayandırmakta olduğu sonucuna varılmıştır.

Aksoy (2016) fuarların Türkiye ihracatı üzerine etkisini açıklarken, araştırmasının sonucunda elde ettiği verilere göre siyasi ve ekonomik koşulların ülkedeki fuarları önemli ölçüde etkilediğini ortaya koymuştur.

Aytekin (2017) firmaların ihtisas fuarlarına yönelmesinin daha faydalı olacağını, bu fuarlar sayesinde sektördeki insanların daha fazla etkileşim içinde olacaklarını ifade etmiştir. Ona göre fuarlar ilişkisel pazarlama yönteminin en etkili biçimde kullanılacağı yerlerden biridir.

Son olarak Tuerxun (2017) uluslararası fuarların dış ticaretteki önemine işaret etmiş; buna örnek olarak Çin ve Türkiye ilişkilerini incelemiştir. Bu ülkelerde düzenlenen fuarların ülkelerin ilişkisini etkileyip etkilemediği üzerinde durarak, olumlu yönde sonuçlara ulaşmıştir.

\subsection{Zihinsel Mesafe}

Öncelikle belirtmek gerekir ki yabancı yazında "psychic distance" olarak geçen kavram bu çalışmada zihinsel mesafe olarak tercüme edilmiştir. Türkçe yazında "psychic" kavramı psikolojik veya algısal gibi farklı terimlerle de ifade edilmektedir (Sümer, 2011; Gödekmerdan, 2012; Karakaş, 2013; Arslan, 2016). Ayrıca bazı çalışmalarda ulusal mesafe 
ya da kültürel mesafe kavramları da zihinsel mesafenin türleri olarak yer almaktadır (Ayas, 2017; Yacouba, 2017).

Zihinsel mesafe, ilgili yazında oldukça yaygın irdelenen ve tanımı konusunda çeşitli bakış açılarının bulunduğu bir kavramdır (Dow, 2000). Terim olarak ilk kez Beckerman'ın (1956: 38) çalışmasında kullanıldığı bilinmekte ve dış ticarette kişiler arası iletişimdeki güçlükleri yansıtan bir kavram olarak ifade edilmektedir. Daha formel bir tanıma göre; zihinsel mesafe bir piyasadan gelen veya piyasaya giden bilgi akışını engelleyen unsurların toplamıdır (Johanson ve Vahlne, 1977: 24). Bu bilgi akışı iki yönlüdür: (1) yabancı pazardaki bilginin firmaya aktarılması ve (2) ürün bilgisinin firmadan pazara aktarılması (Child vd., 2002). Bu bilgi akışını aksatan zihinsel mesafe, uluslararası işletmecilikte neden bazı firmaların başarılı diğerlerinin ise başarısız olduğunun açıklanmasında potansiyel güce sahiptir (Magnusson ve Boyle, 2009: 79). İşletmelerin ana ülkesi ile hedef ülke arasındaki zihinsel mesafe yakın olduğunda stratejilerini daha kolay planlayıp uygulayabiliyorken; zihinsel mesafenin uzak kabul edildiği pazarlar için faaliyetlerin kararlaştırılması ve sonuçlarını hesaplaması nispeten zordur.

Geçmişten günümüze zihinsel mesafe kavramı uluslararası pazar seçimi ve pazarlama stratejileri ile ilişkilendirilmiş ve bunlar üzerindeki etkisi tartışılmıştır. Çünkü bu konularda doğru karar verebilmek ve göze alınacak riski minimize edebilmek için pazar hakkında mümkün olduğunca fazla bilgi edinilmesi gerekmektedir. Brewer (2007: 44-45) zihinsel mesafe ve bilgi arasındaki ilişkiyi şu şekilde açıklamıştır: Yeni bir pazara girerken bir firmanın yöneticileri, bilgi edinmenin kolay olduğu pazarlara yönelirler ve bilgi edinmesi zor olan pazarlardan kaçınırlar. En azından uluslararasılaşma süreçlerinin başlarındayken bu böyledir. İlk yurt dışı faaliyetlerin planlanmasında düşük zihinsel mesafeli pazarların seçilme ihtimali daha yüksektir.

Zihinsel mesafe genelde çok boyutlu bir kavram olarak ele alınmaktadır. Kavramı oluşturduğu düşünülen başlıca unsurlar aşağıda derlenmiştir (Dow ve Karunaratna, 2006; Sousa ve Bradley, 2008; Hakanson ve Ambos, 2010; Gödekmerdan, 2012).

- Coğrafya: Coğrafi mesafe zihinsel mesafe kavramını oluşturan faktörlerden biridir ve olgu üzerinde baskın bir etkisi vardır. İki ülke arasındaki coğrafi mesafe ne kadar fazla ise; bu ülkeler arasında algılanan zihinsel mesafenin de o kadar büyük olduğu kabul edilir. Ancak bu durumun istisnaları da söz konusudur. Buna ABD ve Küba örnek olarak verilebilir. Coğrafi olarak birbirlerine oldukça yakın olmalarına rağmen, siyasi sebeplerden ötürü bu iki ülke arasındaki zihinsel mesafe fazladır.

- Saat dilimi: Saat dilimi boylam bakımında coğrafi mesafe ile değişkenlik gösterir. Örneğin aralarında 12 saat fark olan New York ve Pekin şehirlerindeki toplumlar günü aynı anda yaşamazlar. Mevcut teknolojilere rağmen anlık iletişim kurmakta zorlanırlar. Şehirlerden birinde gündüz iken diğerinde gecedir, birinde mesai saatiyken diğer şehirde mesai bitmiştir. Saat dilimindeki farklılık ülkeler arasında bilgi akışını zorlaştırdığından zihinsel mesafeyi yaratan boyutlardan biri haline gelmektedir.

- Dil: Zihinsel mesafeyi etkileyen temel unsurlardan birinin dil olduğunu kabul edilebilir. Toplumların konuştuğu dilin farklı olması onların birbirleriyle anlaşmasını ve bilgi alışverişini zorlaştırır.

- Kültür: Yazındaki bazı çalışmalarda kültürel mesafe ile zihinsel mesafe kavramlarını birbirinin alternatifi gibi kullanmış olmasına rağmen kültürel mesafe zihinsel mesafenin 
bileşenlerinden yalnızca biridir. Toplumların yaşayış biçimlerindeki farklılıklar onların birbirlerini yabancı algılamasına sebep olur. Farklılıklar arttıkça zihinsel mesafe olumsuz yönde etkilenir.

- Din: Zihinsel mesafeyi oluşturan bir diğer unsur dindir. Dini değerleri ve pratikleri birbirine benzeyen toplumlar arasındaki zihinsel mesafe daha azken, bunlar farklılaştıkça zihinsel mesafenin de fazla olduğu gözlemlenebilir.

- Toplumsal değerler: Her toplumun kendine özgü değerleri vardır. Buna örnek olarak ulusal marş, bayrak veya ortak tarihi geçmiş verilebilir. Farklı toplumlar aynı değerleri taşımadıkları için birbirlerine karşı mesafe hissederler. $\mathrm{Bu}$ da zihinsel mesafenin boyutlarından biri olarak kabul edilmektedir.

- Politik ve yasal sistem: Politik ve yasal sistemler ülkeden ülkeye farklılık gösterir. Bu farklılıklar arttıkça bireyin yabancı bir sisteme ayak uydurması hatta onu anlayıp öğrenmesi hem zordur hem de zaman alır. Bu süreçte birey ortama yabancılaşabilir ve böylece zihinsel mesafe olumlu bir yön almayabilir.

- Ekonomi: Ülkelerin iktisadi yapılarındaki farklılıklar iş yapma alışkanlıklarına kolayca yansımaktadır. Toplumdaki kurumların işleyişi ve hatta refah seviyesindeki ayrışma insanların birbirine uyumunu zorlaştırır ve zihinsel mesafe algısını da artırırlar.

- Eğitim seviyesi: Eğitim seviyesi hem iş hem de sosyal iletişim açısından için önemlidir. Toplumların eğitim seviyesi birbirinden ne kadar farklıysa zihinsel mesafelerinin de o derece olumsuz etkilenmiş olması beklenir.

İlgili yazında zihinsel mesafe uluslararası ticaret ile yakından ilişkilendirilerek farklı isimlerle anılmış ve farklı boyutlarla ölçülmeye çalışılmıştır. Araştırmalarda sıklıkla, genel kabul gören birkaç temel çalışma (Beckerman, 1956; Johanson ve Wiedersheim-Paul, 1975; Johanson ve Vahlne, 1977; Kogut ve Singh, 1988; Evans ve Mavondo, 2002; Prime vd. 2009) üzerine inşa edilerek anlamlı ölçekler geliştirmek amaçlanmıştır. Bu çabanın önemli sebeplerinden biri zihinsel mesafeyi oluşturan farklılıkların yönetilebilmesini, kontrol edilmesini veya takip edilmesini kolaylaştırmaktır. Çünkü bu farklılıklar uluslararası ticaretin önünde engel veya zorluk olarak görülmektedir ve bunun ölçülebilmesi, firmalara girecekleri yeni pazarlar hakkında vermeleri gereken kararlar konusunda fayda sağlayacaktır.

Dow (2000), çalışmasında zihinsel mesafenin ihracat pazarına giriş kararları üzerindeki etkisini açıklamaya çalışmıştır. Yazara göre pazara giriş konusunda alınan ilk karar sonrasında zihinsel mesafenin etkisi büyük ölçüde azalır ama yine de önemli bir yol gösterici olarak kalır.

Brouthers ve Brouthers (2001), çalışmalarında ulusal kültürdeki farklılıklarının firmaların pazara giriş tercihlerini nasıl etkilediğini tartışmış; Orta ve Doğu Avrupa'ya yatırım yapan firmalar üzerine bir araştırma yapmışlardır. Çalışma sonucuna göre kültürel mesafe giriş yöntemlerini yakından ilgilendirmektedir. Kültürel mesafenin yüksek olduğu pazarlarda yatırım riski de yüksek olacağından firmalar işbirlikçi giriş yöntemlerini seçerken, kültürel mesafenin düşük olduğu pazarlarda doğrudan yatırımı tercih etmektedirler.

Evans ve Mavondo (2002) çalışmalarında zihinsel mesafeyi algılanan mesafe ve bu algıyı yaratan faktörler ile açıklayarak daha işlevsel bir kullanım sunmaya çalışmışlardır. Zihinsel mesafeyi iki pazar arasındaki mesafe biçiminde tanımlamışlardır. Mesafe kavramı bu pazarlar arasındaki kültürel ve işle ilgili farklılıkların sonuçları olarak ortaya çıkmaktadır. Özetle zihinsel mesafeyi; iş mesafesi ve kültürel mesafe olmak üzere iki boyutla açıklamışlardır. 
Child vd. (2002) Hong Kong firmaları üzerinde yaptığı incelemeler temelinde zihinsel mesafe ve uluslararasılaşma ilişkisini ele almışlardır. Uluslararasılaşmayla ilişkisi açısından mesafe faktörlerini; mesafe yaratan, mesafeyi azaltan ve mesafeyi köprüleyen faktörler olarak üç grupta sınıflandırmış ve analitik bir çerçeve oluşturmuşlardır.

Ellis (2008) çalışmasında, zihinsel mesafesinin hedef pazarın boyutu ve firmalar açısından pazara girişte öncelik sırası arasındaki ilişkiyi hafifletip hafifletmediğine cevap aramıştır. Bulgulara göre her firma en büyük pazara girmek ister ancak pazarlar arasındaki farklılıklar, belirsizlikler ve riskler artıkça yöneticiler büyük pazar yerine küçük ve daha aşina oldukları pazarları seçmeye yönelmektedirler.

Prime vd. (2009) Fransız üretici firmaların ihracat yöneticileri ile görüşmeler yapmış ve bunlardan toplanan verilerle zihinsel mesafenin çeşitli boyutlarını ortaya koymuşlardır. Boyutlar makro çevredeki, iş çevresindeki ve bireylerin davranışlarındaki farklılıkları içermiştir. Temellendirilmiş bir zihinsel mesafe teorisi oluşturması açısından yol gösterici bir çalışmadır.

Sousa ve Lengler (2009) çalışmalarında Brezilyalı firmaların ihracat girişimlerinde pazarlama stratejisi ve zihinsel mesafe arasındaki ilişkiyi ele almışlardır. Çalışmada, uluslararası pazara uyum sağlayabilme derecesinin yöneticilerin yabancı pazara karşı algıladığı zihinsel mesafeden etkilendiği sonucuna varılmıştır. Ayrıca, beklentilere aykırı olarak zihinsel mesafenin firmanın ihracat performansına olumlu yönde bir etkisi olduğu ortaya konulmuştur.

Hakanson ve Ambos (2010) çalışmalarıyla dünyanın en büyük 25 ekonomisini coğrafi, siyasi ve ekonomik faktör boyutlarında internet temelli bir anket çalışmasından topladıkları verilerle karşılaştırmış ve ülkeler arası zihinsel mesafeleri sayısallaştırmışlardır.

Hakanson ve Dow (2012) ülkeler arası mesafelerin küreselleşme üzerindeki rolünü ele almışlardır. Burada coğrafi mesafe ile zihinsel mesafenin uluslararası ticaret üzerine etkisi karşılaştırılmıştır. 1962 ile 2008 yılları arasını kapsayan verilerle ulaştıkları bulgu, zihinsel mesafenin ticarete etkisinin azaldığı yönündedir. Yazarlara göre coğrafi mesafenin etkisi ülkeler arasındaki ticarette benzeşik olan ürünler için artmış, fakat farklılık gösteren ürünler için nispeten azalmıştır.

Virvilaite ve Seinauskiene (2015) uluslararası ticaret tecrübesine sahip olmanın, ihracat performansına ek olarak, zihinsel mesafenin olumsuz etkisini hafifleteceğini savunmuşlardır.

Ojala (2015) mesafe kavramını coğrafi mesafe, kültürel mesafe ve zihinsel mesafe olarak üç boyuta ayırmıştır. Buna göre mesafenin uluslararası ticarete etkisi bu üç boyutta incelenmelidir.

Dinner vd. (2019) pazarlama krizleri süreçlerinde zihinsel mesafenin çok uluslu şirketlerin performansına etkisini ele almışlar; özellikle iştiraklerin çok yakın ve çok uzak ülkelerde bulunduğu hallerde krizlerin zarar verdiğini ortaya koymuşladır.

Türkiye bağlamında zihinsel mesafenin ele alındığı çalışmaların sayısı oldukça sınırlıdır. Konu ile ilgili çalışmalar söz konusu kavramı genellikle psikolojik mesafe veya algısal mesafe olarak ifade etmektedirler.

Sümer (2011) tarafından yapılan çalışmada uluslararası pazarlamada psikolojik mesafe ile ürün stratejisi arasındaki ilişki ele alınmıştır. Çalışmada, psikolojik mesafenin ürün strateji kararları üzerinde etkili olduğu varsayılmıştır. Türkiye'de şeker ve çikolatalı ürünler olarak 
sınırlandırılmış gıda alt grubunda faaliyet gösteren ihracatçılar ile yapılan anket çalışması ile toplanan veriler, psikolojik mesafe arttıkça ürün adaptasyonunun arttı̆̆ 1 ve standardizasyonun düştüğü sonucunu vermiştir. Diğer bir ifadeyle, ürün stratejisi kararları ile psikolojik mesafe arasında anlamlı bir ilişki olduğu ortaya konmuştur.

Gödekmerdan (2012), uluslararasılaşma sürecinde psikolojik mesafenin rolünü belirlemeyi amaçlamıştır. Psikolojik mesafeyi farklı birçok boyut temelinde ele almış ve ihracat miktarları üzerinde bazı boyutların etkisi olduğunu göstermiştir.

Karakaş (2013) söz konusu kavramı algısal mesafe olarak ifade etmiştir. Algısal mesafenin Türkiye'deki büyük işletmelerin uluslararasılaşma süreçleri üzerine etkili olup olmadığını araştırmıştır. Çalışma kapsamında yapılan anket sonuçlarına göre Almanya ile Türkiye arasındaki algısal mesafenin yüksek olduğu saptanmıştır. Buna rağmen Almanya'nın en önemli yabancı pazarlardan biri olması, algısal mesafenin Türk yöneticilerinin hedef pazar seçimi kararlarında pek de etkili olmadığına işaret etmektedir.

Arslan (2016) tarafından ortaya konulan çalışmada ise psikolojik mesafenin fiyatlandırma kararları üzerine etkisi incelenmiştir. Çalışmada, Türk otomotiv sektöründeki lüks segment araç markaları örneklem olarak alınmış; psikolojik mesafe ile fiyat düzeyi arasında anlamlı ilişkiye rastlanmıştır.

Yukarıda aktarılan ilgili çalışmaların bir kısmı fuarların ticarette bilgi alışverişindeki rolünü vurgularken diğer bir kısmı da zihinsel mesafenin uluslararasılaşma sürecindeki etkilerine işaret etmektedir. Öte yandan, yazında bu iki olgu arasındaki ilişkiyi irdeleyen ampirik bir çalışmaya rastlanmamıştır. Oysa uluslararası fuar katılımı, zihinsel mesafeyi değiştirebilecek bir eylemdir. Çünkü fuar planlaması, ziyaret edilecek ülke ve organizasyona dair hazırlık yapılmasını içermektedir. Ayrıca sektörel istihbarat toplanması, fuar sırasında ve sonrasında yeni kaynaklarla bilgi paylaşımının sürdürülmesi de önemlidir. Kurulan iletişim kanalları ve genişleyen bilgi dağarcı̆̆ı sayesinde, özellikle ev sahibi ülkeye karşı zihinsel mesafenin kısmen de olsa azalması olağandır. Bu mantıksal bağlantıya dayanarak, çalışmanın hipotezi aşağıdaki şekilde oluşturulmuştur.

Hipotez: Uluslararası fuar katılımı ile zihinsel mesafe negatif yönlü ilişkilidir.

\section{ARAŞTIRMA}

$\mathrm{Bu}$ çalışmada, endüstriyel alanda yaygın şekilde gerçekleşen yurt dışı fuar ziyaretleri ile uluslararası ticaretin bariyerlerinden biri olan zihinsel mesafe arasındaki ilişkiyi anlamak adına kesitsel bir araştırma tasarlanmıştır ve detayları aşağıdaki bölümlerde açıklanmıştır.

\subsection{Araştırma Modeli}

Araştırmanın bağımsız değişkeni olan uluslararası fuar katılımı (bundan sonra kısaca fuar katılımı olarak anılacaktır), yabancı katılımcıların daha önce Türkiye'de ziyaret ettiği fuar sayısı ile operasyonalize edilmiştir. Bağımlı değişken olan zihinsel mesafenin nasıl ölçüldüğü sonraki kısımda açıklanmıştır. Kontrol değişkenleri ise sırasıyla; katılımcıların (1) Türkiye'de iş yaptığı bir firmanın olup olmaması, (2) Türkiye'de kaç yıldır iş yaptığı ve (3) Türkiye'yi fuarlar dışında ziyaret sıklığıdır. Bu kontrol değişkenlerinin seçilmesinin sebebi, Türkiye ile fuar harici gerçekleşen temasların da ülke hakkındaki bilgi düzeyini artırdığı varsayımıdır. Bu değişkenlerin modele eklenmesiyle bağımlı ve bağımsız değişkenler arasındaki ilişkinin daha gerçekçi hesaplanacağı düşünülmüştür. Araştırma modeli Şekil 1'de sunulmuştur. 


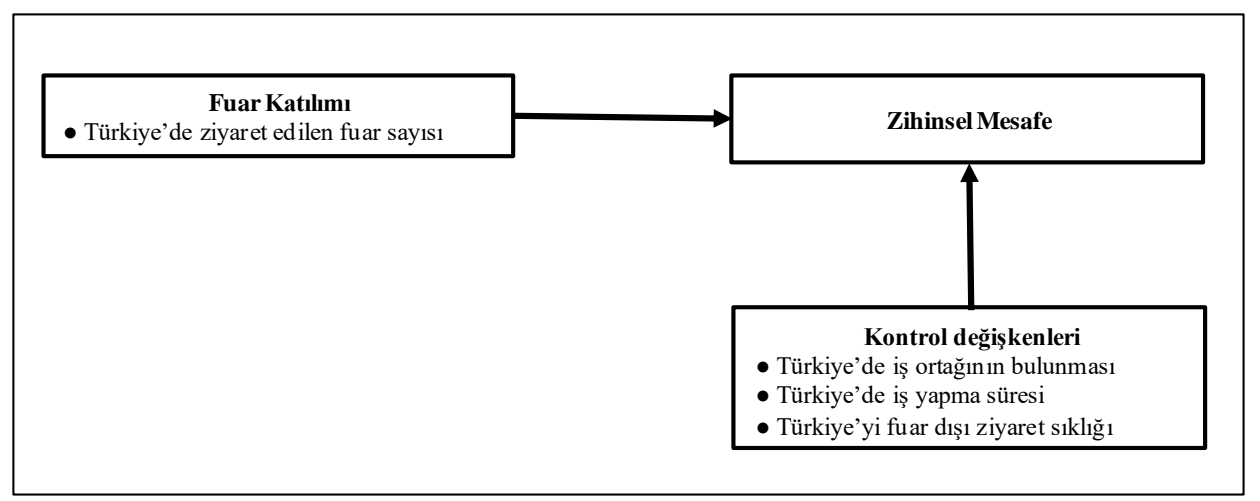

Şekil 1. Araştırma modeli

\subsection{Veri Toplama Aracı}

Veri toplama aracı, iki bölümden oluşan ve fuarlara katılan yabancılara uygulayabilmek adına İngilizce hazırlanan bir anket formudur.

İlk bölümde katılımcıları tanımaya yönelik altı adet kapalı uçlu soru bulunmaktadır. Bu sorular araştırmacılar tarafından geliştirilmiştir. Sorular şunlardır:

1. Türkiye'de müşteriniz ya da tedarikçiniz var mı?

2. Türkiye'deki müşterilerle veya tedarikçilerle kaç yıldır ticaret yapıyorsunuz?

3. Türkiye'yi yılda ortalama kaç kez ziyaret ediyorsunuz?

4. Türkiye'de kaç defa fuarlarda bulundunuz?

5. Kaç yabancı ülke ile ticaret yapıyorsunuz?

6. Firmanızın menşei hangi ülkedir?

Anket formunun ikinci bölümünde, Zihinsel Mesafe Ölçeğini belirleyebilmek için öncelikle Prime vd.'nin (2009) çalışmasından uyarlanan taslak soru formu ile 23-27 Nisan 2019 tarihinde düzenlenen 25. Evteks 2019 fuarı ziyaret edilmiş ve fuarda bulunan yabancı katılımcılarla görüşmeler yapılmıştır. Bu pilot çalışmadaki gözlemlerin ardından anket formuna son şekli verilmiştir. Uyarlanmış ölçekteki boyutlar; makro çevre, kültürel çevre ve iş çevresi olarak isimlendirilmiştir. Birinci boyutta Türkiye'ye dair ekonomik koşullar, politik sistem, yasal sitem, eğitim seviyesi, teknolojik altyapı ve iklim şartları hakkında ifadeler vardır. İkinci boyut Türkiye'deki dil, iletişim şekli ve insanların sahip olduğu değerler ve âdetler hakkında ifadeler içermektedir. Üçüncü boyutta ise; Türkiye'de iş insanları ile ilişkiler geliştirme, işbirlikçilik, müzakere stilleri, güvenilirlik, zaman yönetimi ve diş ticaret prosedürlerine dair ifadeler bulunmaktadır.

Anket formundaki soru ifadelerinde 6'lı semantik farklılık ölçeği kullanılmıştır. Katılımcıların belirtilen konular hakkında "ne düzeyde bilginiz var?" sorusuna 0 ile 5 arasında cevap vermesi beklenmiştir. 0 (sıfır) "Hiç", 5 (beş) ise "Çok iyi” anlamına gelmektedir.

\section{3. Örneklem ve Verilerin Toplanması}

Anketi gerçekleştirmek için İstanbul'da düzenlenen toplam 6 fuar, kolayda örnekleme yöntemiyle seçilerek ziyaret edilmiştir. Bu fuarlar aşağıda listelenmiştir. 
- 61. Uluslararası Ayakkabı Yan Sanayi Fuarı: 2-5 Mayıs 2019, CNR EXPO İstanbul.

- 7. Exposhoes Istanbul: 14-17 Mayis 2019, Pullman Istanbul Hotel and Convention Center.

- 5. Çin Ürünleri Fuarı: 23-25 Mayıs 2019, İstanbul Fuar Merkezi.

- 25. Uluslararası Enerji ve Çevre Fuarı: 28-30 Mayıs 2019, İstanbul Fuar Merkezi.

- 9. Tavukçuluk ve Teknolojileri Uluslararası İhtisas Fuarı: 13-15 Haziran 2019, İstanbul Fuar Merkezi.

- 42. Yapı Fuarı İstanbul: 18-22 Haziran 2019, TÜYAP Fuar ve Kongre Merkezi İstanbul.

Saha araştırmasında hem ülke değişkenini sabitlemek hem de önemli bir pazarı yansıtmak amacıyla iradi olarak anketin sadece Çinli temsilcilerle yapılmasına karar verilmiştir.

Yüz yüze anket yöntemiyle toplanan 112 formun 12'si kullanılamaz olarak değerlendirilmiş ve sonuçta analiz edilecek veri seti 100 gözlemi kapsamıştır.

\subsection{Analiz ve Bulgular}

Türkiye'de fuar katılımı veya ziyareti amacıyla bulunan Çinli firma temsilcilerinden oluşan 100 kişilik örneklem grubuna ilişkin tanımlayıcı bilgiler Tablo 1'de sunulmuştur.

Tablo 1. Örneklem özellikleri

\begin{tabular}{rc}
\hline Türkiye ile ticaret yapıyor mu? & N=100 \\
Evet & 67 \\
Hayır & 33 \\
\hline Türkiye ile kaç yıldır ticaret yapıyor? & \\
0 & 33 \\
$1-5$ arası & 45 \\
$6-10$ arası & 17 \\
11 ve ūzeri & 5 \\
\hline
\end{tabular}

Türkiye'ye yılda kaç kez geliyor?

\begin{tabular}{rr} 
l'den az & 45 \\
1 & 41 \\
2 & 10 \\
3 ve üzeri & 4 \\
\hline
\end{tabular}

Türkiye'de daha ōnce kaç fuar ziyaret etti?

\begin{tabular}{rc}
0 & 36 \\
1 & 46 \\
2 & 13 \\
3 ve ūzeri & 5 \\
\hline
\end{tabular}

Araştırmaya katılan firmaların \%67'sinin Türkiye'de bir müşterisi veya tedarikçisi bulunmaktadır. Firmaların \%5'i Türkiye ile en az 11 yıldır ticaret yapmaktadır. \%17'sinin 610 yıl arası, \%45'inin de 1-5 yıl arası Türkiye ile iş yapma tecrübesi bulunmaktadır. Türkiye'ye yılda ortalama en az $3 \mathrm{kez}$ gelenlerin oranı $\% 4 ; 2$ kez gelenlerin $\% 10 ; 1 \mathrm{kez}$ gelenlerin $\% 41$ ve daha nadir gelenlerin oranı da $\% 45$ 'tir. Türkiye'de daha önce fuara 
katılımları ise; \%5 oranında en az 3 kez; \%13'ü 2 kez; \%46'sı 1 kez katılmıştır ve kalan \%36'sı ise daha önce hiç katılmamıştır.

Katılımcıların Türkiye ile iş yapma durumuna bakıldığında, çoğunluğun en fazla 5 yıllık tecrübesi olduğu ve Türkiye ziyaretlerinin de nadiren yapıldığı anlaşılmaktadır.

Zihinsel mesafe ölçeğinin güvenilirliği, içsel tutarlılık ölçüsü olarak kullanılan Cronbach'ın alfa katsayısıyla değerlendirilmiştir (Şencan, 2005). Değer 0.957 olarak hesaplanmıştır ve genel kabul gören alt limit olan 0.70'in üzerindedir.

Ölçekteki değişkenlerin ortalama ve standart sapma değerleri Tablo 2'de sunulmuştur.

Tablo 2. Değişkenlerin ortalama ve standart sapma değerleri

\begin{tabular}{lcc}
\hline Değişkenler & $\begin{array}{c}\text { Ortalama } \\
(\mathbf{N = 1 0 0})\end{array}$ & $\begin{array}{c}\text { Standart } \\
\text { Sapma }\end{array}$ \\
\hline Ekonomik koşullar & 2,71 & 1,274 \\
Politik sistem & 2,28 & 1,326 \\
Yasal sistem & 1,92 & 1,376 \\
Eğitim seviyesi & 1,97 & 1,329 \\
Teknolojik altyapı & 2,34 & 1,343 \\
İklim & 2,95 & 1,431 \\
Dil & 1,02 & 1,326 \\
İletişim şekli & 2,34 & 1,372 \\
İnsanların sahip olduğu değerler ve adetler & 2,21 & 1,445 \\
İş insanları ile ilişkiler geliştirme & 2,71 & 1,388 \\
İşbirlikçilik & 2,60 & 1,378 \\
Müzakere stilleri & 2,46 & 1,424 \\
Güvenilirlik & 2,51 & 1,345 \\
Zaman yönetimi & 2,33 & 1,311 \\
Diş ticaret prosedürleri & 2,88 & 1,335 \\
\hline
\end{tabular}

İfadelerin değişkenler hakkındaki bilgi düzeyini ölçen 0-5 arası semantik farklılık ölçeği içerdiği hatırlanacak olursa; katılımcıların Türkiye hakkında orta seviyede (değerlerin tümü 3’ün altında) bilgi sahibi olduğu gözlemlenmiştir.

Ölçek için faktör analizine geçmeden önce KMO ve Bartlett testleri yapılmıştır. KMO düzeyi 0.926; Barlett ki-kare istatistiği $\mathrm{p}<0.01$ olarak hesaplanmıştır. Bu değerler ile ölçek faktör analizine uygun bulunmuştur (Yong ve Pearce, 2013).

Ölçek için temel eksen faktör analizi (varimax döndürme yöntemi) uygulanmıştır. Analiz sonucunda, faktör yükleri 0.40 ve üzeri olan değişkenler dikkate alındığında (Şencan, 2005), 2 faktörlü bir yapı ortaya çıkmıştır. Faktör yükü düşük olduğu için "dil” değişkeni ölçekten çıkarılmıştır Tespit edilen bu faktörler toplam varyansın \%69'unu açıklamaktadır. Buna göre ortaya çıkan iki faktör boyutu aşağıda açıklanmaktadır. 
Faktör 1: Değişkenlerden ekonomik koşullar, politik sistem, yasal sitem, teknolojik altyap1, eğitim seviyesi ve iklim olmak üzere altısının oluşturduğu faktör "Dış Çevre Mesafesi” olarak isimlendirilmiştir.

Faktör 2: Güvenilirlik, işbirlikçilik, iş insanları ile ilişkiler geliştirme, zaman yönetimi, ihracat ve ithalat prosedürleri, müzakere stilleri, iletişim şekli ve insanların sahip olduğu değerler ve adetler olmak üzere sekiz değişkenin oluşturduğu faktör "İş Kültürü Mesafesi” olarak isimlendirilmiştir.

Bu iki boyutlu yapıyı oluşturan değişkenlerin faktör yükleri Tablo 3'te sunulmuştur.

Tablo 3. Faktör yükleri

\begin{tabular}{lcc}
\hline Değişkenler & \multicolumn{2}{c}{ Faktörler } \\
& $\mathbf{1}$ & $\mathbf{2}$ \\
\hline Ekonomik koşullar & $\mathbf{0 , 8 0 5}$ & 0,341 \\
Politik sistem & $\mathbf{0 , 7 6 3}$ & 0,296 \\
Yasal sistem & $\mathbf{0 , 7 5 5}$ & 0,369 \\
Teknolojik altyap1 & $\mathbf{0 , 6 6}$ & 0,362 \\
Eğitim seviyesi & $\mathbf{0 , 6 5 1}$ & 0,476 \\
İklim & $\mathbf{0 , 5 8 3}$ & 0,385 \\
Güvenilirlik & 0,263 & $\mathbf{0 , 8 2 0}$ \\
İşbirlikçilik & 0,375 & $\mathbf{0 , 8 1 5}$ \\
İş insanları ile ilişkiler geliştirme & 0,433 & $\mathbf{0 , 7 5 8}$ \\
Zaman yönetimi & 0,394 & $\mathbf{0 , 7 2 5}$ \\
Diş ticaret prosedürleri & 0,381 & $\mathbf{0 , 7 1 5}$ \\
Müzakere stilleri & 0,461 & $\mathbf{0 , 7 1}$ \\
İletişim şekli & 0,571 & $\mathbf{0 , 6 6 2}$ \\
İnsanların sahip olduğu değerler ve adetler & 0,529 & $\mathbf{0 , 6 5 9}$ \\
\hline
\end{tabular}

“Dış Çevre Mesafesi” ve "İş Kültürü Mesafesi” değişkenleri, faktör yapısında ortaya çıkan maddelerin aritmetik ortalamasıyla hesaplanmıştır. Verilerin tümü aralıklı ölçek olmadığından, tablo parametrik olmayan analiz yöntemi Spearman'ın sıralama korelasyon katsayısı (rho) ile hazırlanmıştır. Değişkenler arası korelasyonlar Tablo 4'te sunulmuştur.

Tablo 4. Değişkenler Arası Korelasyonlar

\begin{tabular}{|c|c|c|c|c|c|c|}
\hline Değişkenler & 1 & 2 & 3 & 4 & 5 & 6 \\
\hline 1. Tūrkiye'de iş ortağının bulunması & 1 & & & & & \\
\hline 2. Tūrkiye ile iş yapma sūresi &, $720^{* *}$ & 1 & & & & \\
\hline 3. Tūrkiye’yi ziyaret sıklığı &, $378^{* *}$ &, $397^{* *}$ & $\mathbf{1}$ & & & \\
\hline 4. Türkiye'de ziyaret ettiği fuar sayısı & ,305 &, $307^{* *}$ &, $621^{* *}$ & 1 & & \\
\hline 5. Diş Çevre Mesafesi & $206^{*}$ & $279^{* *}$ & $289^{* *}$ & $207^{*}$ & 1 & \\
\hline 6. İş Kūltūrū Mesafesi & $283^{* *}$ &, $317^{* *}$ &, $337^{* *}$ & $215^{*}$ &, $804^{* *}$ & 1 \\
\hline
\end{tabular}

$902 \mathbf{p}_{\mathbf{p}}<\mathbf{0 , 0 5 ; * *} \mathrm{p}<\mathbf{0 , 0 1}$ 
Burada hatırlatılması gereken bir nokta, mesafe değişkenlerindeki yüksek değerlerin katılımcının bilgi düzeyinin arttığını göstermesidir. Diğer bir deyişle, mesafe değişkeninin değeri azaldıkça zihinsel mesafe artmaktadır.

Regresyon analizinde, veriler parametrik olmadığından, ordinal regresyon yöntemi kullanılmıştır (Norusis, 2012).

Regresyon analizinin ilk aşamasında, bağımlı değişken olarak "Dış Çevre Mesafesi"; bağımsız değişken olarak "Türkiye'de ziyaret edilen fuar sayısı” ve kontrol değişkenleri olarak ise; "Türkiye'de iş ortağının bulunması", "Türkiye ile iş yapma süresi” ve "Türkiye'yi ziyaret sıklığı" modele dâhil edilmiştir. Bulgular 5, 6, 7, 8 ve 9 numaralı tablolarda sunulmuştur.

Tablo 5. Model uygunluğu

\begin{tabular}{lcccc}
\hline Model & -2 LogLikelihood & Ki-kare & df & Sig. \\
\hline Intercept Only & 507,653 & & & \\
Final & 490,946 & 16,707 & 4 & 0,002 \\
\hline
\end{tabular}

Tablo 6. Uygunluk

\begin{tabular}{lccc}
\hline & Ki-kare & df & Sig. \\
\hline Pearson & 1149,251 & 1246 & 0,976 \\
Deviance & 420,895 & 1246 & 1 \\
\hline
\end{tabular}

Tablo 7. Psödo R-kare

\begin{tabular}{ll}
\hline \multicolumn{2}{c}{ Psödo R-kare } \\
\hline Cox and Snell & 0,154 \\
Nagelkerke & 0,154 \\
McFadden & 0,027 \\
\hline
\end{tabular}

Tablo 8. Parametre kestirimleri

\begin{tabular}{|c|c|c|c|c|c|c|c|}
\hline \multirow[b]{2}{*}{ Değişken } & \multirow[b]{2}{*}{ Tahmin } & \multirow{2}{*}{\multicolumn{2}{|c|}{ Standart }} & \multirow[b]{2}{*}{ df } & \multirow[b]{2}{*}{ Sig. } & \multicolumn{2}{|c|}{$\begin{array}{c}95 \% \\
\text { Güven aralığı }\end{array}$} \\
\hline & & & & & & $\begin{array}{l}\text { Lower } \\
\text { Bound }\end{array}$ & $\begin{array}{l}\text { Upper } \\
\text { Bound }\end{array}$ \\
\hline Türkiye ile iş yapma süresi & 0,063 & 0,051 & 1,53 & 1 & 0,216 & $-0,037$ & 0,162 \\
\hline Türkiye'yi ziyaret sıklı̆̆ı & 0,775 & 0,263 & 8,69 & 1 & 0,003 & 0,260 & 1,291 \\
\hline Türkiye'de ziyaret ettiği fuar sayısı & $-0,105$ & 0,274 & 0,148 & 1 & 0,700 & $-0,642$ & 0,431 \\
\hline Türkiye'de iş ortağı olmayanların sayıs1 & $-0,142$ & 0,455 & 0,097 & 1 & 0,755 & $-1,033$ & 0,749 \\
\hline Türkiye'de iş ortağı olanların sayısı & $0^{\mathrm{a}}$ & . & . & 0 & . & . & . \\
\hline
\end{tabular}

Tablo 9. Paralel çizgiler testi

\begin{tabular}{lcccc}
\hline Model & -2 LogLikelihood & Ki-kare & df & Sig. \\
\hline Null Hypothesis & 490,946 & & & \\
General & $381,383^{\mathrm{a}}$ & $109,563^{\mathrm{b}}$ & 96 & 0,163 \\
\hline
\end{tabular}


Yukarıdaki bulgular ışığında araştırmanın bağımsız değişkeni olan “Türkiye'de ziyaret edilen fuar sayısı" ile "Dış Çevre Mesafesi" arasında istatistikî olarak anlamlı bir ilişki saptanmamıştır. Öte yandan, "Türkiye'yi ziyaret sıklığı” kontrol değişkeni ile "Dış Çevre Mesafesi” arasında istatistikî olarak anlamlı bir ilişki tespit edilmiştir. Diğer kontrol değişkenleri olan “Türkiye'de iş ortağının bulunması" ve "Türkiye ile iş yapma süresi” ile bağımlı değişken arasında belirgin bir ilişki gözlenmemiştir.

Regresyon analizinin ikinci aşamasında, bağımlı değişken olarak "İş Kültürü Mesafesi”; bağımsız değişken olarak "Türkiye'de ziyaret edilen fuar sayısı"; kontrol değişkenleri olarak da yine "Türkiye'de iş ortağının bulunması", "Türkiye ile iş yapma süresi” ve "Türkiye'yi ziyaret sıklığı" modelde kullanılmıştır. Bulgular 10, 11, 12, 13 ve 14 numaralı tablolarda sunulmuştur.

Tablo 10. Model uygunluğu

\begin{tabular}{lcccc}
\hline Model & $\mathbf{- 2 ~ L o g L i k e l i h o o d ~}$ & Ki-kare & df & Sig. \\
\hline Intercept Only & 557,21 & & & \\
Final & 540,268 & 16,942 & 4 & 0,002 \\
\hline
\end{tabular}

Tablo 11. Uygunluk

\begin{tabular}{lccc}
\hline & Ki-kare & df & Sig. \\
\hline Pearson & 1583,552 & 1696 & 0,975 \\
Deviance & 463,285 & 1696 & 1 \\
\hline
\end{tabular}

Tablo 12. Psödo R-kare

\begin{tabular}{ll}
\hline \multicolumn{2}{c}{ Psödo R-kare } \\
\hline Cox and Snell & 0,156 \\
Nagelkerke & 0,156 \\
McFadden & 0,025 \\
\hline
\end{tabular}

Tablo 13. Parametre kestirimleri

\begin{tabular}{|c|c|c|c|c|c|c|c|}
\hline \multirow[b]{3}{*}{ Değişken } & \multirow[b]{3}{*}{ Tahmin } & \multirow{2}{*}{\multicolumn{2}{|c|}{ Standart }} & \multirow[b]{3}{*}{ df } & \multirow[b]{3}{*}{ Sig. } & \multicolumn{2}{|c|}{ 95\% Güven } \\
\hline & & & & & & Lower & Upper \\
\hline & & Hata & Wald & & & Bound & Bound \\
\hline Türkiye ile iş yapma süresi & 0,066 & 0,051 & 1,696 & 1 & 0,193 & $-0,033$ & 0,166 \\
\hline Türkiye'yi ziyaret sıklığı & 0,604 & 0,259 & 5,444 & 1 & $\mathbf{0 , 0 2 0}$ & 0,097 & 1,112 \\
\hline Türkiye'de ziyaret ettiği fuar sayısı & $-0,194$ & 0,274 & 0,5 & 1 & 0,479 & $-0,73$ & 0,343 \\
\hline Türkiye'de iş ortağı olmayanların sayısı & $-0,474$ & 0,456 & 1,077 & 1 & 0,299 & $-1,368$ & 0,421 \\
\hline Türkiye'de iş ortağı olanların sayısı & $0^{\mathrm{a}}$ & . & . & 0 & . & . & . \\
\hline
\end{tabular}

Tablo 14. Paralel çizgiler testi

\begin{tabular}{llccc}
\hline Model & -2 LogLikelihood & Ki-kare & df & Sig. \\
\cline { 2 - 6 } Null Hypothesis & 540,268 & & & \\
General & $196,238^{\mathrm{a}}$ & $344,030^{\mathrm{b}}$ & 132 & 0,000 \\
\hline
\end{tabular}


Bu bulgulara göre "Türkiye'de ziyaret edilen fuar sayısı” bağımsız değişkeni ile "İş Kültürü Mesafesi” arasında istatistikî olarak anlamlı bir ilişki saptanmamıştır. Diğer yandan, “Türkiye’yi ziyaret sıklığı” kontrol değişkeni ile "İş Kültürü Mesafesi” arasında istatistikî olarak anlamlı bir ilişki tespit edilmiştir. Öteki kontrol değişkenleri olan "Türkiye'de iş ortağının bulunması" ve "Türkiye ile iş yapma süresi” ile bağımlı değişken arasında belirgin bir ilişki gözlenmemiştir.

Regresyon analizleri sonucuna göre fuar ziyareti sayısı ne "Dış Çevre Mesafesi” ile ne de "İş Kültürü Mesafesi” ile istatistikî olarak anlamlı bir ilişki göstermektedir. Dolayısıyla, fuar katılımı ile zihinsel mesafe arasında negatif yönlü bir ilişki olduğunu öne süren araştırma hipotezi desteklenmemiştir. Çalışma sonucunda ortaya çıkan bir bulgu ise; araştırmaya katılanların "Türkiye'yi ziyaret sıklı̆gı" ile zihinsel mesafeleri arasında negatif yönde belirgin bir ilişki olduğu; diğer bir ifadeyle Türkiye hakkındaki bilgi düzeylerinin arttığıdır.

\section{DEĞERLENDIRME VE SONUÇ}

$\mathrm{Bu}$ çalışmada uluslararası ticaret açısından iki önemli olgu arasındaki ilişki tespit edilmeye çalışılmıştır. Güncel fuar istatistikleri Türkiye'de düzenlenen fuarların ve özellikle yabancı katılımcı sayılarının artışını göstermektedir (TOBB, 2020). Bu yönüyle fuarların, ticari ortamdaki rolünün sürdüğü düşünülebilir. Diğer taraftan da mesafenin, firmaların uluslararasılaşma kararlarındaki etkisi, yazında halen popüler bir araştırma alanıdır. Mesafe türlerinden biri olan zihinsel mesafe ise; kavramsallaştırılması ve ölçülmesi nispeten zor da olsa, çok boyutlu bir kavram olarak irdelenmeye değer bulunan bir olgudur. Ancak, ilgili yazında teorik ve pratik değeri kabul edilen bu iki konunun ilişkisini ele alan çalışmalara rastlanmamaktadir.

$\mathrm{Bu}$ araştırmada fuar katılımı ve zihinsel mesafe bağlantısı incelenmekle beraber, bir yönüyle de Türkiye-Çin ticari ilişkilerinden bir kesit sunulmaktadır. Çin, 2018 yılında 4,6 trilyon ABD Dolarının üzerindeki dış ticaret hacmiyle, dünyada lider konumdadır (DTÖ, 2020). Türkiye ile Çin arasındaki dış ticaret hacmi de 2019 yılında 20 milyar ABD Dolarının üzerinde gerçekleşmiştir ve bu bakımdan Türkiye'nin en büyük üçüncü ticari ortağıdır (Ticaret Bakanlığı, 2020). Dolayısıyla, araştırmanın bağlamının da anlamlı olduğu söylenebilir.

Türkiye ile Çin arasındaki zihinsel mesafenin nispeten uzak olduğu daha önce yapılan çeşitli çalışmalarda ortaya konmuştur (Hakanson ve Ambos, 2010; Sümer, 2011; Hofstede Insights, 2019). Keza bu araştırmaya katılanların da, yazındaki bulgularla örtüşen şekilde, Türkiye'yi ziyaret etmiş olmalarına rağmen, ülke hakkındaki bilgi düzeylerinin vasat olduğu gözlemlenmiştir. Araştırmaya katılanların Türkiye hakkında en az bilgiye sahip oldukları konu "Dil" değişkenidir. Coğrafi mesafe, dil ailesi ve kullanılan alfabe dikkate alındığında, Çinlilerin Türkçeye aşina olmaması şaşırtıcı değildir. Diğer yandan, firma temsilcilerinin en çok bilgi sahibi oldukları konular; "İklim", "Dış ticaret prosedürleri" ve "Ekonomik koşullar" değişkenleridir. Yabancı ziyaretçilerin, kısa süreli de olsa gidecekleri ülkenin hava durumuna göz atmaları olağandır. Elbette, firma temsilcilerinin iş yapmaya niyetli oldukları ülkenin iktisadi şartları ve uluslararası ticaret uygulamaları hakkında bilgi edinmeleri de doğaldır.

Araştırmada yalın bir mantıksal bağlantıyla oluşturulan "uluslararası fuar katılımı ile zihinsel mesafe negatif yönlü ilişkilidir" hipotezi; fuar ziyaretlerinin ne diş çevre ne de iş kültürü mesafelerini etkilediği bulgusu dolayısıyla desteklenmemiştir. Buna gerekçe olarak sunulabilecek bir yorum; Çinli firmaların genel mesai anlayışı, dil bariyeri ve başka 
milletlerden insanlarla da yapılan temaslardan ötürü, fuar saatleri içinde veya dişında yerel çevreyle zengin bir iletişim kanalı kuramamış olma ihtimalidir.

Bulgulara göre aralarında negatif yönlü ilişki olan iki değişken ise; ülkeye fuar dışı yapılan ziyaret sıklığı ile zihinsel mesafedir. Keza bu beklenen bir durumdur, çünkü fuar harici yapılan ziyaretler ülke ve sektör hakkında, yerli iş ortakları kanalıyla gerçekleşen bilgi akışını yansıtmaktadır. Zaten bu yüzden, fuar dışı ziyaretler araştırma modelinde kontrol değişkeni olarak bulunmaktadır.

Elbette çalışmanın yöntem bakımından bazı kısıtları mevcuttur. Başta, kolayda örnekleme yoluyla seçilen altı fuarda bulunan tek bir ülkenin temsilcilerinden kesitsel veri toplanmıştır. Ayrıca sahadaki zaman darlığından ve kullanılan yabancı dilden ötürü anket formlarının olabildiğince sadeleştirilmesi gerekmiştir. Bunlarla birlikte, elde edilen verinin çoğu parametrik değildir ve istatistikî analiz yöntemleri de buna göre seçilmiştir. Bu kısıtlar araştırma bulgularının genellenebilirliğini zorlaştırsa da, kullanılan model ve ölçeklerin içsel tutarlılığının, sonuçları kendi kapsamında güçlü kıldığı varsayılabilir.

Teorik açıdan, bu çalışma uluslararası ticarette önemli bir bariyer olarak kabul edilen zihinsel mesafenin zamanla nasıl değişebileceğini irdeleyen araştırmalara örnek teşkil edebilir. Diğer yandan çalışma, yöneticilere yabancı ülkelere ziyaret planlama sürecinde, eğer amaç hedef ülkeden bilgi akışı sağlamak ise, fuar katılımı ile müşteri ziyareti arasındaki tercihte yön gösterebilecektir.

\section{KAYNAKÇA}

AKSOY, C. (2016). Türkiye'de Fuar Organizasyonlarının İhracatına Etkisi, Yüksek Lisans Tez, Namık Kemal Üniversitesi Sosyal Bilimler Enstitüsü, Tekirdağ.

ARSLAN, B. (2016). Küresel İşletmelerin Fiyatlandırma Kararlarında Psikolojik Mesafenin Etkisi, Yüksek Lisans Tezi, Bahçeşehir Üniversitesi Sosyal Bilimler Enstitüsü, İstanbul.

AYAS, S. (2017). Ulusal Mesafe ve Örgütsel Öğrenmenin Sınır-Ötesi Şirket Satın Almaları Üzerine Etkisi: 2006-2015 Avrupa Örneği, Doktora Tezi, Gaziantep Üniversitesi Sosyal Bilimler Enstitüsü, Gaziantep.

AYTEKİN, I. (2017). İlişkisel Pazarlama Perspektifinden İhtisas Fuarlarına Katılımın Fuar Performansina Etkisi, Yüksek Lisans Tezi, Ege Üniversitesi Sosyal Bilimler Enstitüsü, İzmir.

BECKERMAN, W. (1956). "Distance and the Pattern of Intra-European Trade", The Review of Economics and Statistics. 38(1): 31-40.

BREWER, P.A. (2007). “Operationalizing Psychic Distance: A Revised Approach”, Journal of International Marketing, 15(1): 44-66.

BROUTHERS, K.D. \& BROUTHERS, L.E. (2001). "Explaining the National Cultural Distance Paradox", Journal of International Business Studies, 32 (1): 177-189.

CHILD J., NG, S.H. \& WONG, C. (2002). "Psychic Distance and Internationalization: Evidence from Hong Kong Firms", International Studies of Management and Organization, 32(1): 36-56. 
ÇEKİÇ, M. (2009). Pazarlama Faaliyetleri İçinde Fuarlar - Endüstri Kuruluşlarının Fuarlara Yönelik Tutumları ve Madencilik Sektöründe Uygulama, Yüksek Lisans Tezi, Anadolu Üniversitesi Sosyal Bilimler Enstitüsü, Eskişehir.

DINNER, I. M., KUSHWAHA, T. \& STENKAMP, J-B.E.M. (2019). "Psychic Distance and Performance of MNCs during Marketing Crises", Journal of International Business Studies, 50: 339-364.

DOW, D. (2000). “A Note on Psychological Distance and Export Market Selection”, Journal of International Marketing, 8(1): 51-64.

DOW, D. \& KARUNARATNA, A. (2006). "Developing a Multidimensional Instrument to Measure Psychic Distance Stimuli”, Journal of International Business Studies, 37: 578-602.

DTÖ, Dünya Ticaret Örgütü. (2020), “World Trade Statistical Review 2019”, https://www.wto.org/english/res_e/statis_e/wts2019_e/wts2019_e.pdf, 14.03.2020.

DÜNYA BANKASI, "Exports of Goods and Services (Current US\$)", https://data.worldbank.org/indicator/NE.EXP.GNFS.CD, 10.03.2020.

ELLIS, P.D. (2008). "Does Psychic Distance Moderate the Market Size-Entry Sequence Relationship?", Journal of International Business Studies, 39: 351-369.

ERDEMİ, A. (2017). 1939 New-York Dünya Fuarı'nda Türkiye, Yüksek Lisans Tezi, Atatürk Üniversitesi Atatürk İlkeleri ve İnkılâp Tarihi Enstitüsü, Erzurum.

EVANS, J. \& MAVONDO, F. T. (2002). "Psychic Distance: The Construct and Measures", American Marketing Association, 13: 308-314.

GÖDEKMERDAN, L. (2012). Psikolojik Mesafenin Uluslararasılaşma Sürecindeki Rolü: Türkiye'nin İhracatı Üzerine Bir Araştırma, Doktora Tezi, Atatürk Üniversitesi Sosyal Bilimler Enstitüsü, Erzurum.

GREGORY, S. \& BREITER, D. (2001). "Trade Show Managers: Profile in Technology Usage", Journal of Convention \& Exhibition Management, 3(3): 63-76.

GÜREL, Ş.E. (1998). “Etken Bir Satış Geliştirme Tekniği: Fuarlar”, Ekonomik Vizyon İzmir Ticaret Odası Dergisi, 68(31): 52-58.

HAKANSON, L. \& AMBOS, B. (2010). "The Antecedents of Psychic Distance”, Journal of International Management, 16(3): 195-210.

HAKANSON, L. \& DOW, D. (2012). "Markets and Networks in International Trade: On the Role of Distances in Globalization", Management International Review, 52: 761 789.

HANSEN, K. (2004). "Measuring Performance at Trade Shows: Scale Development and Validation", Journal of Business Research, 57: 1-13.

HOFSTEDE INSIGHTS, “Country Comparison”, https://www.hofstede-insights.com/ country-comparison/china,turkey, 24.07.2019 
İNCE, E.Ş. (2013). Türkiye'de Kobilerin Pazarlama İletişimi Planlarında İhtisas Fuarlarına ve Yayınlarına Yaklaşımı. (Yüksek Lisans Tezi). Yeditepe Üniversitesi Sosyal Bilimler Enstitüsü. İstanbul.

JIN, X., WEBER, K. \& BAUER, T. (2012). "Relationship Quality between Exhibitors and Organizers: A Perspective from Mainland China's Exhibition Industry", International Journal of Hospitality Management, 31: 1222-1234.

JOHANSON, J. \& VAHLNE, J-E. (1977). "The Internationalization Process of the Firm - A Model of Knowledge Development and Increasing Foreign Market Commitments", Journal of International Business Studies, 8: 23-32.

JOHANSON, J. \& WIEDERSHEIM-PAUL, F. (1975). “The Internationalization of the FirmFour Swedish Cases”, The Journal of Management Studies, 12(3): 305-322.

KARAKAŞ, Ş. (2013). Psychic Distance and the Internationalization Process of Large Turkish Corporations, Yüksek Lisans Tezi, Boğaziçi Üniversitesi Sosyal Bilimler Enstitüsü, İstanbul.

KOGUT, B. \& SINGH, H. (1988). "The Effect of National Culture on the Choice of Entry Mode”, Journal of International Business Studies, 19(3): 411-432.

KOLDAŞ, A.N. (2006). Ticari Fuarların Satış Geliştirme Etkisi ve Bir Uygulama, Yüksek Lisans Tezi, Gazi Üniversitesi Sosyal Bilimler Enstitüsü, Ankara.

LI, L. (2010). “Antecedents and Effect of Internet Implementation for Trade Shows”, Journal of Business \& Industrial Marketing, 25(4): 272-283.

MAGNUSSON, P. \& BOYLE, B.A. (2009). "A Contingency Perspective on Psychic Distance in International Channel Relationships", Journal of Marketing Channels, 16: 77-99.

MEB, Milli Eğitim Bakanlığı. (2011). "Halkla İlişkiler ve Organizasyon Hizmetleri Alanı Çerçeve Öğretim Programı", http://mufredat.meb.gov.tr/Dosyalar/201919111347544-halkla ilişkiler ve organizasyon hizmetleri_çöp_11.pdf, 06.06.2019.

NORUSIS, M.J. (2012). IBM SPSS Statistics 19 Advanced Statistical Procedures Companion, Prentice Hall, New Jersey.

OJALA, A. (2015). "Geographic, Cultural, and Psychic Distance to Foreign Markets in the Context of Small and New Ventures", International Busines Review, 24(5): 825-835.

PAKER, S. (2009). Satış Geliştirme Yöntemi Olarak Fuarcılık ve Güncel Bir Uygulama. (Yüksek Lisans Tezi). Haliç Üniversitesi Sosyal Bilimler Enstitüsü. İstanbul.

PEHLIVAN, A.Ç. (1996). Fuarcılık Türkiye ve Avrupa Fuarcılığına Karşılaştırmalı Bir Bakış, Yüksek Lisans Tezi, İstanbul Üniversitesi Sosyal Bilimler Enstitüsü. İstanbul.

PRIME N., OBADIA, C. \& VIDA, I. (2009). "Psychic Distance in Exporter-Importer Relationships: A Grounded Theory Approach", International Business Review, 18: 184-198. 
SARMENTO, M., SIMÕES, C. \& FARHANGMEHR, M. (2015). “Applying a Relationship Marketing Perspective to B2B Trade Fairs: The Role of Socialization Episodes", Industrial Marketing Management, 44: 131-141.

SOHODOL, Ç. (2003). Bütünleşik Pazarlama İletişimi Sürecinde Ticari İhtisas Fuarlarının Önemi; Fuar Katılım ve Organizasyonunun Stratejik Planlanması, Yüksek Lisans Tezi, Ege Üniversitesi Sosyal Bilimler Enstitüsü, İzmir.

SOUSA, C.M.P. \& BRADLEY, F. (2008). "Cultural Distance and Psychic Distance: Refinements in Conceptualisation and Measurement", Journal of Marketing Management, 24(5-6): 467-488.

SOUSA, C.M.P. \& LENGLER, J. (2009). "Psychic Distance, Marketing Strategy and Performance in Export Ventures of Brazilian Firms", Journal of Marketing Management, 25(5-6): 591-610.

SÜLÜN, U. (2006). İhracatın Geliştirilmesinde Fuar, Sergi ve Panayırlara Yönelik Mali Teşviklerin Etkinliği (1990 - 2005 Dönemi Analizi), Yüksek Lisans Tezi, Dokuz Eylül Üniversitesi Sosyal Bilimler Enstitüsü, İzmir.

SÜMER, S.I. (2011). Uluslararası Pazarlamada Psikolojik Mesafe ve Ürün Stratejileri Arasındaki İlişki: Ampirik Bir Değerlendirme, Doktora Tezi, Gazi Üniversitesi Sosyal Bilimler Enstitüsü, Ankara.

ŞENCAN, H. (2005). Sosyal ve Davranışsal Ölçümlerde Güvenilirlik ve Geçerlilik, Seçkin, Ankara.

TANNER, J. (2002). "Leveling the Playing Field: Factors Influencing Trade Show Success for Small Companies”, Industrial Marketing Management, 31: 229-239.

TİCARET BAKANLIĞI. (2020). "Ülkelere Göre Diş Ticaret”, https://ticaret.gov.tr/ istatistikler/dis-ticaret-istatistikleri/dis-ticaret-istatistikleri-ocak-ekim-2019/ulkeleregore-dis-ticaret, 12.03.2020.

TOBB, Türkiye Odalar ve Borsalar Birliği. (2020). “2019 Fuar İstatistikleri”, https://tobb.org.tr/FuarlarMudurlugu/Sayfalar/Istatistikler.php, 10.03.2020.

TOBB, Türkiye Odalar ve Borsalar Birliği. (2015). "Yurt İçinde Fuar Düzenlenmesine Dair Usul ve Esaslar", https://www.tobb.org.tr/FuarlarMudurlugu/Sayfalar/FuarlarMevzuat $\quad$.html, 06.06.2019.

TUERXUN, Y. (2017). Uluslararası Fuarların Dış Ticaretteki Önemi - Çin ve Türkiye'de Düzenlenen Fuarlara Katılımın Değerlendirilmesi, Yüksek Lisans Tezi, İstanbul Ticaret Üniversitesi Dış Ticaret Enstitüsü, İstanbul.

VIRVILAITE, R. \& SEINAUSKIENE, B. (2015). "The Influence of Psychic Distance on Export Performance: The Moderating Effects of International Experience", Procedia-Social and Behavioral Sciences, 213: 665-670.

YACOUBA, M.S.M. (2017). The Effect of Cultural Distance, Familiarity and Country Image on Purchase Intentions, Yüksek Lisans Tezi, Anadolu Üniversitesi Sosyal Bilimler Enstitüsü, Eskişehir. 
YONG, A.G. \& PEARCE, S. (2013). “A Beginner's Guide to Factor Analysis: Focusing on Exploratory Factor Analysis", Tutorials in Quantitative Methods for Psychology, 9(2): 79-94. 